\title{
PLGA-GENTAMICIN BIOCOMPOSITE MATERIALS WITH POTENTIAL ANTIMICROBIAL APPLICATIONS IN ORTHOPEDICS
}

\author{
MARIA-VIORICA CIOCÎLTEU ${ }^{1}$, PAULINA PODGOREANU ${ }^{2 *}$, CRISTINA DELCARU $^{2}$, \\ MARIANA-CARMEN CHIFIRIUC ${ }^{2}$, COSTEL VALENTIN MANDA ${ }^{1}$, ANDREI BIŢĂ ${ }^{1}$, \\ MARIANA POPESCU ${ }^{1}$, EMILIA AMZOIU ${ }^{1}$, OCTAVIAN CROITORU ${ }^{1}$, CORALIA BLEOTU ${ }^{3}$, \\ MARINELA BOSTAN $^{3}$, JOHNY NEAMŢU ${ }^{1}$
}

${ }^{I}$ Faculty of Pharmacy, University of Medicine and Pharmacy of Craiova, Petru Rares Street, 200638, Craiova, Romania ${ }^{2}$ Research Institute of the University of Bucharest (ICUB), Earth, Environmental and Life Sciences Division, University of Bucharest, 36-46 M. Kogălniceanu Boulevard, 050107, Bucharest, Romania

${ }^{3}$ Center of Immunology, "Ștefan S. Nicolau” Institute of Virology, 285 Mihai Bravu Road, 030304, Bucharest, Romania

*corresponding author: podgoreanu.paula@yahoo.com

Manuscript received: January 2019

\begin{abstract}
The purpose of this study was to synthesize a PLGA (polylactic-co-glycolic acid)-gentamicin biodegradable material followed by HPLC determination of the drug's encapsulation efficiency in the polymer. The chosen polymer, PLGA is a biocompatible and biodegradable synthetic polymer, approved by the FDA, with adjustable mechanical properties, highly used as a controlled release drug delivery system. One novel feature of the study is the inclusion of an antibiotic in the composite material to combat the planktonic growth and biofilms formed by some of the major bacterial species involved in the aetiology of osteomyelitis. The double emulsion synthesis method was chosen, as the most suitable for encapsulating water-soluble drugs, such as gentamicin. For the quantitative assay of gentamicin, a new HPLC chromatographic method was used, consisting in an initial treatment with FMOC-Cl (9-fluorenylmethylchloroformate) to derivatize gentamicin, followed by UV detection of the derivative at $\lambda=265 \mathrm{~nm}$. The antibacterial activity of the composite material was confirmed by the qualitative and quantitative assays performed in this study to determine the minimal inhibitory concentration and the minimal biofilm eradicating concentration.
\end{abstract}

\section{Rezumat}

Scopul acestui studiu 1-a reprezentat sinteza unui material biodegradabil de tip PLGA-gentamicină, urmată de determinarea eficienţei de încapsulare a medicamentului în polimer. Polimerul ales, PLGA (acidul poli lactic-co-glicolic) este un polimer sintetic biocompatibil şi biodegradabil, aprobat de FDA, cu proprietăţi mecanice ajustabile, extrem de utilizat ca sistem de cedare controlată a medicamentelor. Un element de noutate al studiului îl reprezintă includerea în materialul compozit a unui antibiotic activ față de creșterea planctonică și față de biofilmele formate de principalele specii bacteriene implicate în etiologia osteomielitei. Ca metodă de sinteză s-a ales metoda emulsiei duble, aceasta fiind cea mai adecvată pentru încapsularea medicamentelor hidrosolubile, precum gentamicina. Pentru determinarea cantitativă a gentamicinei s-a utilizat o metodă cromatografică HPLC nouă, care a presupus iniţial derivatizarea gentamicinei cu clorură de 9-fluorenilmetilcloroformat (FMOC-Cl), urmată de detecţia UV a derivatului la $\lambda=265 \mathrm{~nm}$. Activitatea antibacteriană a compozitului a fost confirmată prin metodele cantitative utilizate pentru determinarea concentrațiilor minime inhibitorii și de eradicare a biofilmului.

Keywords: PLGA, gentamicine, biocomposite, antimicrobial activity assay

\section{Introduction}

A considerable number of studies have reported the use of biodegradable polymers as drug carriers, which can even be inserted as bioresorbable surgical devices $[17,22]$.

Many new organic compounds have been synthesized and characterized $[20,21]$ to establish their biopharmaceutical applications, but of all types of biomaterials, the use of polylactic-co-glycolic acid has a huge potential as a drug transporter and as a matrix for tissue engineering [6]. Biocomposite materials are promising future candidates for biomedical applications. Biocompatible materials typically contain either a natural or synthetic polymer (polymethyl-methacrylate, poly(D,L-lactide-co-glycolide, poly(lactic-co-hydroxymethyl glycolic acid) or a calcium phosphate $\left(\mathrm{Ca}_{10}(\mathrm{PO} 4)_{6}(\mathrm{OH})_{2}[14], \mathrm{Ca}_{3}\left(\mathrm{PO}_{4}\right)_{2}\right.$ [11]) together with an osteoconductive drug (sodium alendronate, strontium ranelate [18]) or broad antibacterial agents (quinolones [4], aminoglycosides).

The therapeutic value of some drugs including gentamicin can be improved by encapsulating them in delivery systems, for example in PLGA microspheres, which can contribute to sustained release of the drug [2]. 
Small molecule drugs are classified biopharmaceutically in hydrophilic or amphiphilic drugs. The first category has good water solubility and it is used for the treatment of many diseases. Clinical use may, however, be limited due to rapid clearance or adverse bioavailability, requiring repeated administration [23]. Gentamicin antibiotic was discovered in 1963 [24], remaining particularly useful in the treatment of resistant bacteria. It has extremely effective bactericidal properties against Gram-negative and some Gram-positive bacteria. Gentamicin is not metabolized, being accumulated in the extracellular space, before kidneys excretion [10]. Its use is limited by its negative effects it has, such as ototoxicity and nephro-toxicity.

Polylactic-co-glycolic acid (PLGA), a copolymer of polylactic acid (PLA) and polyglycolic acid (PGA) (Figure 1) belongs to a class of polymers approved by Food and Drug Administration, due to its exceptional biodegradability and biocompatibility. Various studies show the use of this polymer as a carrier for various types of macromolecules, such as DNA, RNA and peptides, and for drugs [13]. PLGA can encapsulate almost any size molecules.

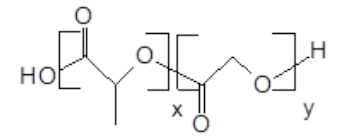

Figure 1.

Polylactic-co-glycolic acid structure: $\mathrm{x}=$ number of units of lactic acid; $y=$ the number of units of glycolic acid

One problem remains the quantitative assay of the drug encapsulated in the composite because it does not absorb in the UV-VIS domain. It may, however, be determined by a HPLC-DAD method after a prederivatization with 9-fluorenylmethyl chloroformate (FMOC-Cl). FMOC-CI was first used as a derivatizing agent in 1983 by Einarsson et al. [5] which determined different amino acids.

\section{Materials and Methods}

All chemicals were of analytical grade and were purchased from Merck (Darmstadt, Germany).

Double emulsion synthesis of PLGA- gentamicin composite

First, an appropriate amount of drug $(150 \mathrm{mg})$ was dissolved in the aqueous phase $(400 \mu \mathrm{L}$ of $0.1 \mathrm{M}$ monosodium phosphate and $0.1 \mathrm{M}$ disodium phosphate, $\mathrm{pH}=6.3$ with $0.5 \%$ PVA) and then this solution, $\mathrm{A}_{1}$, was added to the oily organic phase $(\mathrm{O}), 200 \mathrm{mg}$ of PLGA in $5 \mathrm{~mL}$ of dichloromethane (DCM). The initial water-oil emulsion was stirred vigorously for 2 - 3 minutes at 45,000 rpm with a special SilentCrusher device. Then this phase was added to the second aqueous phase $\left(\mathrm{A}_{2}\right)$, quantitatively more significant ( $0.4 \mathrm{~g}$ of PVA in $40 \mathrm{~mL}$ of water) under stirring. The next step was to evaporate the organic solvent under stirring for 3 hours at $1500 \mathrm{rpm}$.

The resulting suspension was frozen at $-45^{\circ} \mathrm{C}$ then lyophilized at $0.014 \mathrm{mbar}$ and $-9^{\circ} \mathrm{C}$ for 10 hours, then at 0.014 mbar and $20^{\circ} \mathrm{C}$ for a further 10 hours with a lyophiliser. The resulting microparticles were kept at cold, $4-5^{\circ} \mathrm{C}$.

Synthesis of PLGA-hydroxyapatite-gentamicin biocomposite

$150 \mathrm{mg}$ of gentamicin were dissolved in the aqueous phase $\mathrm{A}_{1}(400 \mu \mathrm{L}$ of $0.1 \mathrm{M}$ monosodium phosphate and $0.1 \mathrm{M}$ disodium phosphate, $\mathrm{pH}=6.3$ with $0.5 \%$ PVA) and then vigorously stirred for 2 - 3 minutes at 45,000 rpm with the organic phase O (200 mg PLGA in $5 \mathrm{~mL}$ DCM). The water-oil emulsion obtained was added to the secondary aqueous phase $\mathrm{A}_{2}(0.4 \mathrm{~g}$ of PVA in $40 \mathrm{~mL}$ of water) to which $100 \mathrm{mg}$ of hydroxyapatite were added.

Thereafter, the organic solvent was evaporated, followed by lyophilisation under the experimental conditions described above.

Gentamicin determination in biocomposite by HPLC$D A D$

A Thermo Finnigan Surveyor HPLC System equipped with photodiode array detector and Thermo Finnigan Xcalibur data system was used: i) column: $\mathrm{C}_{18}$ reversed phase column (Thermo Scientific) Hypersil GOLD, $250 \mathrm{~mm}$ x $4.6 \mathrm{~mm}$ I.D., particle size $5 \mu \mathrm{m}$; ii) mobile phase: a mixture of acetonitrile:methanol:water (85:10:5), isocratic elution; flow rate: $1 \mathrm{~mL} / \mathrm{min}$; wavelength: $265 \mathrm{~nm}$.

\section{Calibration curve}

Stock solutions of gentamicin with concentrations range between 0 and $1 \mathrm{mg} / \mathrm{mL}$ were prepared by dissolving the drug in borate buffer $(\mathrm{pH}=9.7)$.

FMOC derivatization of gentamicin was achieved by dissolving FMOC-Cl in methanol $(30 \mathrm{mM})$ and by adding a suitable amount $(0.5 \mathrm{~mL})$ over $1 \mathrm{~mL}$ gentamicin solution. They were left to react for 5 minutes. And then, a volume of $200 \mu \mathrm{L}$ of this solution was diluted by $800 \mu \mathrm{L}$ mobile phase and then injected in the HPLC system.

Samples

An amount of 14 mg PLGA-gentamicin composite and $9 \mathrm{mg}$ PLGA-hydroxyapatite-gentamicin were left with $1 \mathrm{~mL}$ borate buffer $(0.05 \mathrm{M}$ sodium tetraborate + $0.1 \mathrm{M} \mathrm{NaOH}, \mathrm{pH}=9.7$ ), overnight, in order to hydrolyse PLGA. A volume of $0.25 \mathrm{~mL}$ of the hydrolysed solution was filtered through a $0.45 \mu \mathrm{m}$ porous membrane mixed with $0.75 \mathrm{~mL}$ borate buffer and $0.5 \mathrm{~mL}$ FMOC-Cl solution. After 5 minutes, $200 \mu \mathrm{L}$ of this solution was diluted with $800 \mu \mathrm{L}$ mobile phase and injected into the chromatographic system. 
Antimicrobial activity assays

Microbial strains

The antimicrobial activity was tested on two Grampositive (Staphylococcus aureus ATCC 25923, Enterococcus faecalis ATCC-29212) and two Gramnegative (Pseudomonas aeruginosa ATCC 27853, Escherichia coli ATCC 25922) bacterial strains. The tested samples were represented by $10 \mathrm{mg} / \mathrm{mL}$ suspensions in dimethyl sulfoxide (DMSO) and encoded as follows: 1) PLGA-hydroxyapatite-gentamicin; 2) PLGA-gentamicin; 3) Gentamicin control; 4) DMSO negative control.

Quantitative assay of the antimicrobial properties The binary serial micro dilution technique using 96well microtiter plates was used to determine the minimal inhibitory concentration (MIC) values of the tested composites. The quantitative assay was performed in Muller Hinton broth for bacteria, according with CLSI, 2018.

The sterile medium was added in sterile 96-well plates and binary dilutions of each tested suspension were performed in a final volume of $100 \mu \mathrm{L}$. After performing the binary dilutions, $10 \mu \mathrm{L}$ of microbial suspension adjusted to an optical density of 0.5 McFarland $\left(1.5 \times 10^{8} \mathrm{CFU} / \mathrm{mL}\right)$ were added in each well. The MIC values were established by the macroscopic analysis of the wells content and by spectrophotometric measurement of the optical density at $600 \mathrm{~nm}$ using a BIOTEK SYNERGY-HTX ELISA multi-mode reader. Each experiment was performed in triplicate and repeated on at least three separate occasions.

The quantitative assessment of the influence of the tested suspensions on the microbial adherence on the inert substratum

The content of the 96-multi well plastic plates used for the MIC assay were discarded, washed three times with phosphate buffered saline (PBS) and the microbial cells adhered to the plastic walls were fixed with cold methanol for 5 minutes and stained by $1 \%$ violet crystal solution for 15 minutes. The coloured biofilm was thereafter re-suspended by $33 \%$ acetic acid solution. The optical density of the blue suspension was measured at $490 \mathrm{~nm}$ and the obtained values being proportional with the number of the adhered microbial cells.

Cytotoxicity assay

The cytotoxicity effect was tested on MG63 cells (ECACC 86051601) using CellTiter $96^{\circledR}$ AQueous One Solution Cell Proliferation Assay (Promega G3580). For the experiments, $10^{4}$ MG63 cells were plated in each well of 96 well plate, in DMEM:F12 medium supplemented with $10 \%$ bovine foetal serum. After $24 \mathrm{~h}$, the cells were treated with different concentration of gentamicin, PLGA-gentamicin and PLGA-hydroxyapatite-gentamicin (between $1 \mathrm{mg} / \mathrm{mL}$ and $7.6 \mu \mathrm{g} / \mathrm{mL}$ ). Treated and untreated cells were maintained for $72 \mathrm{~h}$ at $37^{\circ} \mathrm{C}, 5 \% \mathrm{CO}_{2}$. The toxicity was evaluated by adding CellTiter $96^{\circledR}$ AQueous One Solution and maintained the cells for $3 \mathrm{~h}$ at $37^{\circ} \mathrm{C}$, and quantification of absorbance at $490 \mathrm{~nm}$, using the plate reader BertholdTech TriStar2S (Berthold Technologies GmbH \& Co. KG, Germany). The results were presented as $\%$ of viability reported to the untreated cells and $\mathrm{IC}_{50}$ calculation.

\section{Results and Discussion}

Double emulsion synthesis of PLGA gentamicin composite

The water-oil-water emulsion method is the most appropriate method for encapsulating water-soluble drugs such as gentamicin, as opposed to simple oilwater emulsion methods, which are ideal for waterinsoluble drugs [25].

Gentamicin determination in biocomposite by HPLC$D A D$

Gentamicin does not have absorption in the UV-Vis domain and therefore its determination is possible after a derivatization reaction with FMOC-Cl.

FMOC-Cl reacts with the primary and secondary amino groups of gentamicin at alkaline $\mathrm{pH}$ and forms quite stable derivatives.

Figure 2 shows how FMOC-Cl binds to a primary and a secondary amino group.

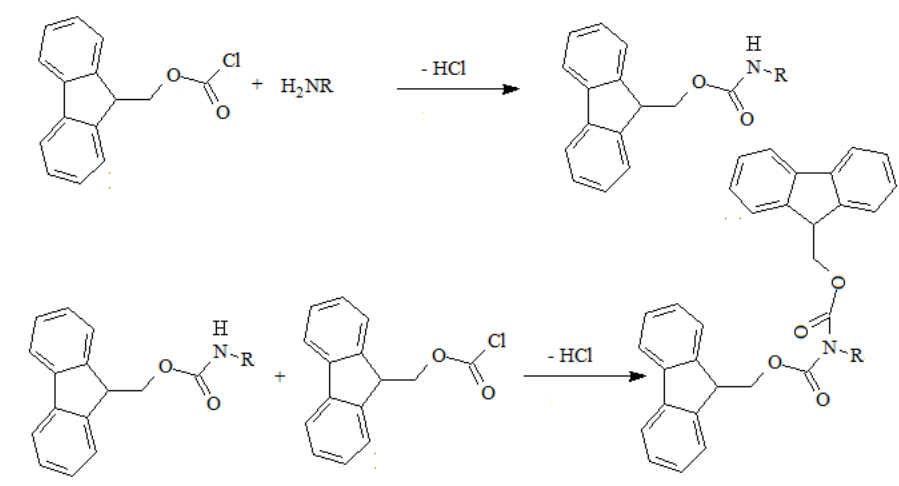

Figure 2.

The reaction between FMOC-Cl and primary or secondary amino groups 
FARMACIA, 2019, Vol. 67, 4

On the HPLC chromatogram when the FMOC-amine solution was injected after the derivatization reaction, chromatographic peaks were observed at a retention time of less than 6 minutes which were attributable to the remaining FMOC-Cl reagent (excess) but also to some products resulting from the hydrolysis reaction of FMOC-Cl (Figure 3), consistent with other results presented in the literature [16].<smiles>O=C(Cl)OCC1c2ccccc2-c2ccccc21</smiles><smiles>COC(C)O</smiles><smiles>O=C(O)OCC1c2ccccc2-c2ccccc21</smiles><smiles>C=C1c2ccccc2-c2ccccc21</smiles>

Figure 3.

The hydrolysis reaction of FMOC-Cl

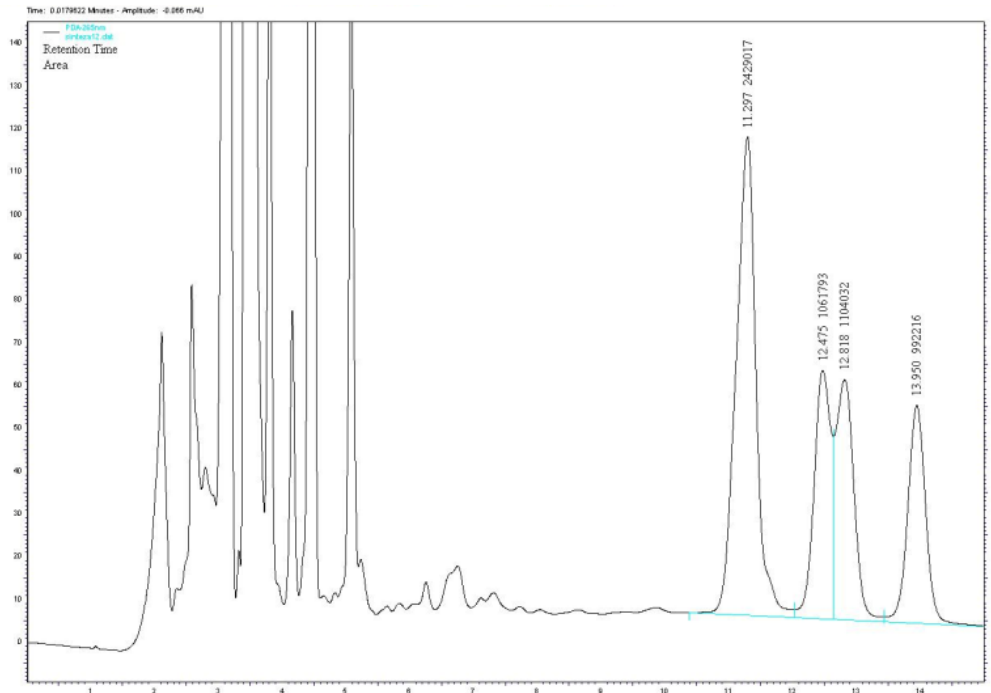

A

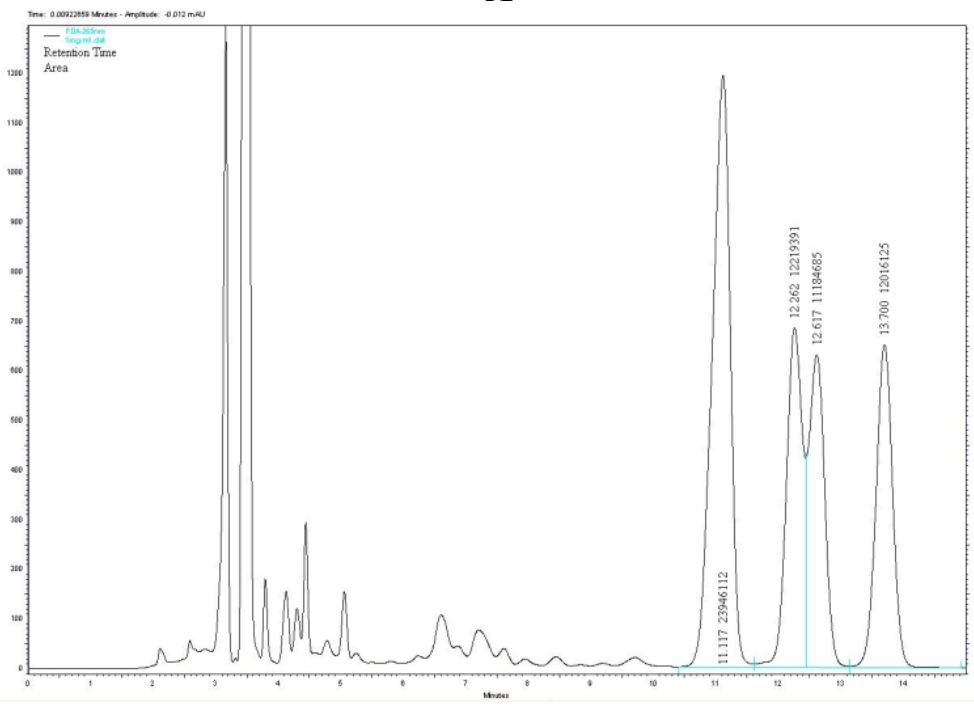

B

Figure 4.

Chromatogram obtained for A) gentamicin standard solution of $1 \mathrm{mg} / \mathrm{mL}$; B) determination of gentamicin from the PLGA-gentamicin microparticles 
FARMACIA, 2019, Vol. 67, 4

From the point of view of the amount of FMOC-Cl required to react with gentamicin, it was taken into account that each primary or secondary amino group reacted with a FMOC-Cl molecular moiety, but also that gentamicin still has in its structure other three glycosidic -OH groups which also can react at neutral $\mathrm{pH}$ with the derivatization agent.

The basic $\mathrm{pH}$ is required not only to ensure a better development for the reaction between amino groups and FMOC as observed by Gao et al. [7] and Korös et al.[14], but also to prevent further reaction of aminoglycoside $\mathrm{OH}$ groups with FMOC-Cl.

As can be seen in the chromatogram of a standard solution of $1 \mathrm{mg} / \mathrm{mL}$ shown in Figure 4A, gentamicin exhibits four peaks characteristic of the four gentamicin isomers, the first at 11.2 minutes, chosen later for quantification. HPLC methods in the literature present data similar to those found in this study [3].

The obtained calibration curve has good linearity in the range of $0.05-1 \mathrm{mg} / \mathrm{mL}(\mathrm{r}=0.996211)$ as depicted in Figure 5.

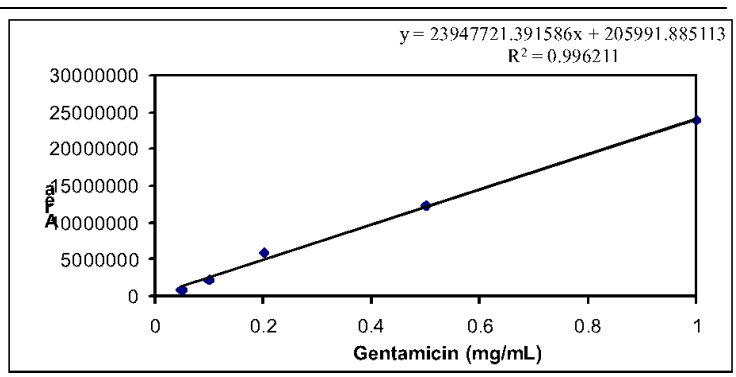

Figure 5.

Calibration curve, obtained for the first characteristic peak (retention time 11.2 minutes) of the four gentamicin isomers

Determination of encapsulation degree

The degree of encapsulation was calculated by plotting the mass of gentamicin recovered by HPLC in the sample ( $0.400 \mathrm{mg}$ gentamicin in PLGA-gentamicin and $0.058 \mathrm{mg}$, respectively in PLGA-HA-gentamicin) to the microparticle mass.

$$
\text { Encapsulation }(\%)=\frac{\text { experimental gentamicin amount }(\mathrm{mg})}{\text { microparticle amount }(\mathrm{mg})} \times 100
$$

Thus we found in PLGA-gentamicin 2.85\% gentamicin, and only $0.64 \%$ gentamicin in PLGA- hydroxyapatitegentamicin biocomposite. The explanation of this small percentage of gentamicin encapsulated in the PLGAhydroxyapatite-gentamicin microparticles results from the fact that part of the hydroxyapatite is encapsulated in PLGA in competition with gentamicin.

Antimicrobial activity

Quantitative screening of the antimicrobial properties In the quantitative assay, the minimal inhibitory concentrations were read by wells observations [1]. In the wells containing high concentrations of compounds the culture growth was no visible, the microbial cells being killed or inhibited by the tested compounds. The results of the quantitative assay revealed that the most susceptible microorganism were $P$. aeruginosa, in which case the composites exhibited the same efficiency as the free antibiotic, as demonstrated by the equal minimal inhibitory concentration value, followed by $S$. aureus strains, when the MIC value of the composite has still remained very low (Table 1). This is particularly important, because the inclusion of gentamicin in hydroxyapatite contributes to the bone reintegration of the implant by improving the biocompatibility of orthopaedic materials, but preserving their antimicrobial activity [19].

Osteomyelitis is the inflammation of the bone marrow secondary to infection, which can progress to osteonecrosis, bone destruction and septic arthritis [15]. Epidemiological studies of the last decade have shown that the increase in the incidence and severity of acute osteomyelitis is associated with Staphylococcus aureus, as the most prevalent pathogen [12], an opportunistic species that can be extremely difficult to treat [9]. A postulated cause of the increased severity of osteomyelitis is the production of a toxin known as pantonvalentine leukocidin (PVL) by S. aureus strains [26]. Many other pathogens were found to be, although less frequently involved in the aetiology of osteomyelitis, such as Pseudomonas aeruginosa, Staphylococcus epidermidis, Escherichia coli, Enterococcus faecalis, Enterococcus faecium, Proteus mirabilis and anaerobic bacteria [8].

Table I

Minimal inhibitory concentration values of the tested suspensions against the tested bacterial strains

\begin{tabular}{|c|c|c|c|c|}
\hline \multirow{2}{*}{ No. } & Bacterial strains & \multicolumn{3}{|c|}{ Minimal inhibitory concentration values (mg/mL) } \\
\cline { 3 - 5 } & & PLGA-hydroxyapatite-gentamicin & PLGA-gentamicin & Gentamicin standard \\
\hline 1 & $\begin{array}{c}\text { Staphylococcus aureus } \\
\text { ATCC 25923 }\end{array}$ & 0.0097 & 0.0097 & 0.00029 \\
\hline 2 & $\begin{array}{c}\text { Enterococcus faecalis } \\
\text { ATCC 29212 }\end{array}$ & 0.31 & 0.31 & 0.0097 \\
\hline 3 & $\begin{array}{c}\text { Pseudomonas aeruginosa } \\
\text { ATCC 27853 }\end{array}$ & 0.0097 & 0.0097 & 0.0097 \\
\hline 4 & $\begin{array}{c}\text { Escherichia coli } \\
\text { ATCC 25922 }\end{array}$ & 0.039 & 0.039 & 0.0005 \\
\hline
\end{tabular}


The quantitative assessment of the influence of the tested suspensions on the microbial adherence on the inert substratum

Concerning the inhibitory activity of the tested suspensions against the growth of the tested bacterial strains in biofilms, the two suspensions (PLGAhydroxyapatite-gentamicin and PLGA-gentamicin) proved to inhibit the adherence of $E$. faecalis strains, proving ineffective against the other monospecific biofilms (Figures 6 - 9). Therefore, we could conclude that the obtained composites are primarily useful against planktonic bacteria, but less effective against bacterial biofilms.

Staphylococcus aureus ATCC 25923

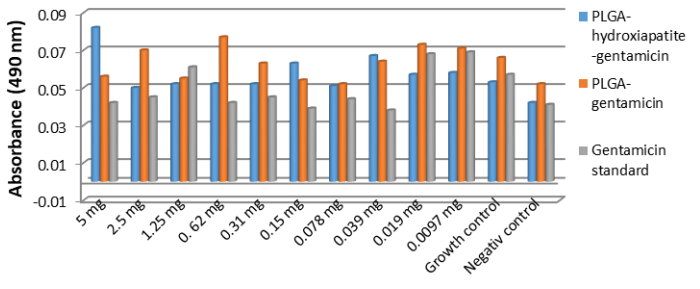

Serial dilutions tested compounds

Figure 6.

Graphic representation of S. aureus ATCC 25923 bacterial biofilm development in the presence of the tested suspensions

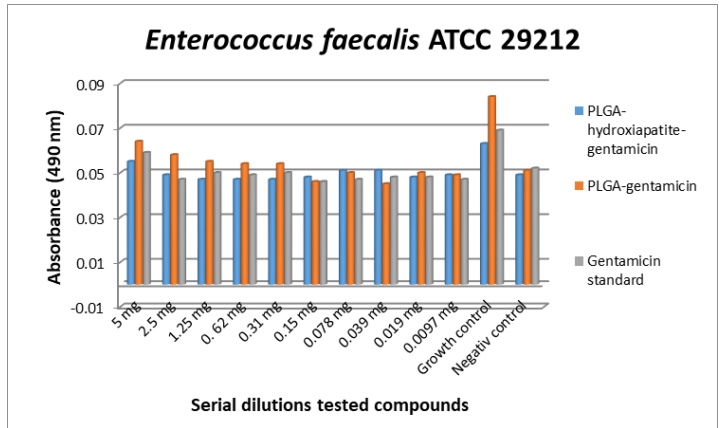

Figure 7.

Graphic representation of E. faecalis ATCC 29212 bacterial biofilm development in the presence of the tested suspensions

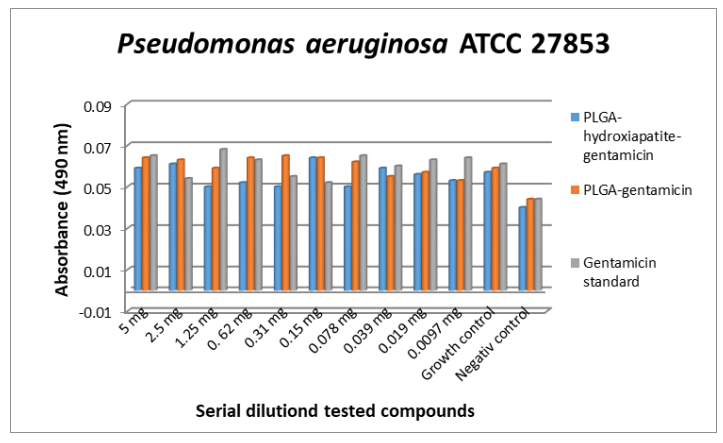

Figure 8.

Graphic representation of $P$. aeruginosa ATCC 27853 bacterial biofilm development in the presence of the tested suspensions
Escherichia coli ATCC 25922

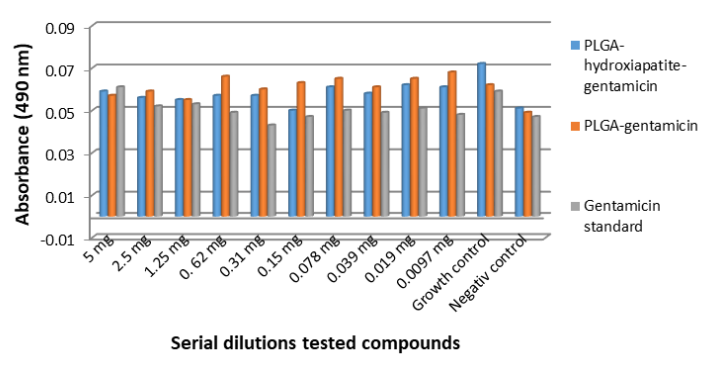

Figure 9.

Graphic representation of E. coli ATCC 25922 bacterial biofilm development in the presence of the tested suspensions

The composite material are quite to be biocompatible because the effects seem to be due only to gentamicin content (gentamicin $\mathrm{IC}_{50}=222.359$, PLGA-gentamicin $\mathrm{IC}_{50}=272.421$, respectively HA-PLGA-gentamicin $\left.\mathrm{IC}_{50}=257.354\right)$ (Figure 10).

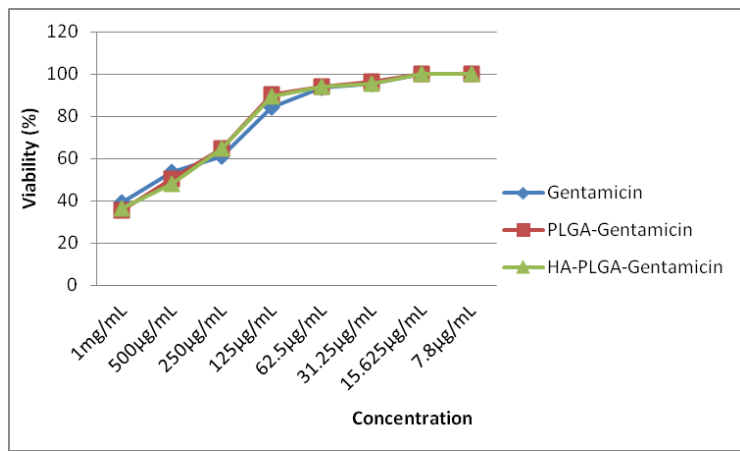

Figure 10.

The effects of gentamicin, PLGA-gentamicin and PLGA-hydroxyapatite-gentamicin on MG63 cells

\section{Conclusions}

The synthesis of a biocompatible composite of PLGAgentamicin and PLGA-hydroxyapatite-gentamicin, respectively, was accomplished using double emulsion synthesis as a method. For the determination of gentamicin in the samples, a new HPLC-DAD analysis method was developed involving a first step of derivatizing gentamicin with FMOC-Cl at $\mathrm{pH}$ 9.7. Detection was performed at $265 \mathrm{~nm}$, the analysis time being relatively short. By including gentamicin and gentamicin together with hydroxyapatite in PLGA, it was obtained a material with antimicrobial properties and biocompatibility so that it could be further optimized to fight orthopaedic infections.

\section{Acknowledgement}

The financial support of the Postdoctoral Fellowship granted by the Research Institute of the University of Bucharest (ICUB), Earth, Environmental and Life Sciences Division, University of Bucharest, Contract 
FARMACIA, 2019, Vol. 67, 4

no. 12895/13.06.2017, as well as PNIII PCE Ideas $142 / 2017$ is gratefully acknowledged.

\section{References}

1. Araniciu C, Oniga $\mathrm{O}$, Marc G, Palage MD, Măruțescu L, Chifiriuc MC, Stoica CI, Ionuț I, Oniga SD, Anti-biofilm activity evaluation and molecular docking study of some 2(3-pyridyl)-thiazolyl-1,3,4oxadiazolines. Farmacia, 2018; 66(4): 627-634.

2. Chaisri W, Ghassemi AH, Hennink WE, Okonogi $\mathrm{S}$, Enhanced gentamicin loading and release of PLGA and PLHMGA microspheres by varying the formulation parameters. Coll Surf B: Biointerfaces, 2011; 84: 508-514.

3. Chuong MC, Chin J, Han JW, Kim E, Alhomayin W, Al Dosary F, Rizg W, Moukhachen O, Williams DA, High performance liquid chromatography of gentamicin sulfate reference standards and injection usp. Int J Pharmaceut Anal., 2013; 4(1): 25-29.

4. Ciocilteu MV, Mocanu AG, Mocanu A, Ducu C, Nicolaescu OE, Manda VC, Turcu-Stiolica A, Nicolicescu C, Melinte R, Balasoiu M, Croitoru O, Neamtu J, Hydroxyapatite-ciprofloxacin delivery system: Synthesis, characterization and antibacterial activity. Acta Pharm., 2018; 68: 129-144.

5. Einarsson S, Josefsson B, Lagerkvist S, Determination of amino acids with 9-fluorenylmethyl chloroformate and reversed-phase high-performance liquid chromatography. J Chromatogr., 1983; 282: 609-618.

6. Flores C, Degoutin S, Chai F, Raoul G, Hornez JC, Martel B, Siepmann J, Ferri J, Blanchemain N, Gentamicin-loaded poly(lactic-co-glycolic acid) microparticles for the prevention of maxillofacial and orthopedic implant infections. Mater Sci Eng C, 2016; 64: 108-116.

7. Gao CX, Krul, IS, Trainor T, Determination of aliphatic amines in air by on-line solid-phase derivatization with HPLC-UV/FL. J Chrom Sci., 1990; 28: 102-108.

8. García del Pozo E, Collazos J, Cartón JA, Camporro D, Asensi V, Bacterial osteomyelitis: microbiological, clinical, therapeutic, and evolutive characteristics of 344 episodes. Revista Espanola de Quimioterapia: Publicacion Oficial de La Sociedad Espanola de Quimioterapia, 2018; 31(3): 217-225.

9. Gheorghe I, Tatu AL, Lupu I, Thamer O, Cotar A, Pircalabioru GG, Chifiriuc CM, Molecular characterization of virulence and resistance features in Staphylococcus aureus clinical strains isolated from cutaneous lesions in patients with drug adverse reactions. Rom Biotechnol Lett., 2017; 22(1): 12321-12327.

10. Gyselynck A, Forrey A, Cutler R, Pharmacokinetics of gentamicin: distribution and plasma and renal clearance. J Infect Dis., 1971; 124 (1): 70-76.

11. Habraken W, Habibovic P, Epple M, Bohner M, Calcium phosphates in biomedical applications: materials for the future?. Mater Today, 2016; 19(2): 69-87.
12. Hendrix AS, Spoonmore TJ, Wilde AD, Putnam NE, Hammer ND, Snyder DJ, Cassat JE, Repurposing the Nonsteroidal Anti-inflammatory Drug Diflunisal as an Osteoprotective, Antivirulence Therapy for Staphylococcus aureus Osteomyelitis. Antimicrob Agents and Chemother., 2016; 60(9): 5322-5330.

13. Jain RA, The manufacturing techniques of various drug loaded biodegradable poly(lactide-coglycolide) (PLGA) devices. Biomaterials, 2000; 21: 2475-2490.

14. Korös A, Hanczkó R, Jámbor A, Qian Y, Perl A, Molnár-Perl I, Analysis of amino acids and biogenic amines. J Chromatogr A, 2007; 1149(1): 46-55.

15. Lee YJ, Sadigh S, Mankad K, Kapse N, Rajeswaran G, The imaging of osteomyelitis. Quantitat Imag Med Surg., 2016; 6(2): 184-198.

16. Lopez MR, Alvarez MJG, Ordieres AJM, Blanco PT, Determination of dimethylamine in groundwater by liquid chromatography and precolumn derivatization with 9-fluorenylmethylchloroformate. J Chromatogr A, 1996; 721: 231-239.

17. Lupuleasa D, Drăgănescu D, Hîncu L, Tudosă CP, Cioacă D, Biocompatible polymers for $3 \mathrm{D}$ printing. Farmacia, 2018; 66(5): 737-746.

18. Mao Z, Fang Z, Yang Y, Chen X, Wang Y, Kang J, Qu X, Yuan W, Dai K, Strontium ranelate-loaded PLGA porous microspheres enhancing the osteogenesis of MC3T3-E1 cells. RSC Adv., 2017; 7: 24607-24615.

19. Neamtu J., Bubulică MV, Rotaru A, Ducu C, Balosache OE, Manda VC, Turcu-Stiolica A, Nicolicescu C, Melinte R, Popescu M, Croitoru O, Hydroxyapatitealendronate composite systems for biocompatible materials. J Therm Anal Calorim., 2017; 127: 15671582.

20. Radu S, Rău G, Moanţă A, Synthesis and characterisation of some 4-[(chlorobenzyl)oxy]azobenzenes. Rev Chim (Bucharest), 2001; 52: 619-622.

21. Rău G, Iacobescu G, Meltzer V, A serie of new azoderivatives-Synthesis and liquid crystal properties. Rev Chim (Bucharest), 2005; 50(2): 119-124.

22. Ulery BD, Nair LS, Laurencin CT, Biomedical Applications of Biodegradable Polymers. J Polym Sci B Polym Phys.. 2011; 49(12): 832-864.

23. Vrignaud S, Benoit JP, Saulnier P, Strategies for the nanoencapsulation of hydrophilic molecules in polymer-based nanoparticles. Biomaterials, 2011; 32: 8593-8604.

24. Weinstein M, Luedemann G, Oden E, Wagman G, Rosselet J, Marquez J, Gentamicin, a new antibiotic complex from Micromonospora. J Med Chem., 1963; 6: 463-464.

25. Wang W, Shi A, Agyei D, Wang Q, Formulation of water-in-oil-in-water $(\mathrm{W} / \mathrm{O} / \mathrm{W})$ emulsions containing trans-resveratrol. RSC Adv., 2017; 7: 35917-35927.

26. Yan L, Jiang DM, Cao ZD, Wu J, Wang X, Wang ZL, Yi F, Treatment of Staphylococcus aureus - induced chronic osteomyelitis with bone-like hydroxyapatite/ poly amino acid loaded with rifapentine microspheres. Drug Design, Develop Ther., 2015; 9: 3665-3676. 